\title{
Shading decreases and delays NDVI and flowering of prostrate Arctic shrubs ${ }^{1}$
}

\author{
Jeremy L. May, Steven F. Oberbauer, Steven L. Unger, Matthew J. Simon, \\ Katlyn R. Betway, and Robert D. Hollister
}

\begin{abstract}
Increases in shrub growth and canopy cover are well documented community responses to climate warming in the Arctic. An important consequence of larger deciduous shrubs is shading of prostrate plant species, many of which are important sources of nectar and berries. Here, we present the impact of a shading experiment on two prostrate shrubs, Vaccinium vitis-idaea L. and Arctous alpina L., in northern Alaska over two growing seasons. We implemented three levels of shading (no shade, $40 \%$ shade, and $80 \%$ shade) in dry heath and moist acidic tundra. Plots were monitored for soil moisture content, surface temperature, normalized difference vegetation index (NDVI), and flowering. Shading was shown to, on average, lower surface temperature $\left(0.7^{\circ} \mathrm{C}\right.$ to $\left.5.3^{\circ} \mathrm{C}\right)$ and increase soil moisture content $(0.5 \%$ to $5.6 \%)$ in both communities. Both species- and plot-level NDVI values were delayed in timing of peak values (7 to 13 days) and decreased at the highest shading. Flower abundance of both species was lower in shaded plots and peak flowering was delayed (3 to 8 days) compared with controls. Changes in timing may result in phenological mismatches and can impact other trophic levels in the Arctic as both the flowers and resulting berries are important food sources for animals.
\end{abstract}

Key words: bearberry, lingonberry, phenology, climate change, Vaccinium vitis-idaea, Arctous alpina.

Résumé : Les augmentations de la croissance des arbustes et du couvert végétal sont des réponses bien documentées des communautés au réchauffement climatique dans l'Arctique. Une conséquence importante des grands arbustes à feuilles caduques est l'ombrage fait aux espèces végétales procombantes, dont beaucoup sont des sources importantes de nectar et de baies. Les auteurs présentent ici l'impact d'une expérience d'ombrage sur deux arbustes procombants, Vaccinium vitis-idaea L. et Arctous alpina L., dans le nord de l'Alaska au cours de deux saisons de croissance. Ils ont mis en place trois niveaux d'ombrage (aucune ombre, $40 \%$ d'ombre et $80 \%$ d'ombre) dans une lande sèche et une toundra acide humide. Les parcelles ont été surveillées pour la teneur en humidité du sol, la température de surface, l'indice de végétation par différence normalisée (NDVI) et la floraison. L'ombrage a permis, en moyenne, d'abaisser la température de surface $\left(0,7\right.$ à $\left.5,3{ }^{\circ} \mathrm{C}\right)$ et d'augmenter la teneur en humidité du sol (0,5 à 5,6 \%) dans les deux communautés. Les valeurs NDVI à l'échelle de l'espèce et de la parcelle étaient retardées quant au moment d'atteinte des valeurs maximales (7 à 13 jours) et diminuaient au niveau de l'ombrage le plus

Received 30 October 2020. Accepted 21 July 2021.

J.L. May,* S.F. Oberbauer, S.L. Unger, and M.J. Simon. Department of Biological Sciences and Institute of the Environment, Florida International University, 11200 SW 8th St., Miami, FL 33199, USA.

K.R. Betway and R.D. Hollister.* Department of Biological Sciences, Grand Valley State University, 1 Campus Dr., Allendale, MI 49401, USA.

Corresponding author: Jeremy L. May (email: jmay010@fiu.edu).

${ }^{1}$ This paper is part of a Special Issue entitled: Impacts of climate change on tundra ecosystems: Three decades of results from the International Tundra Experiment (ITEX).

*Jeremy L. May and Robert D. Hollister served as Guest Editors at the time of manuscript review and acceptance; peer review and editorial decisions regarding this manuscript were handled by Alessandro Petraglia and Greg Henry.

Copyright remains with the author(s) or their institution(s). This work is licensed under a Creative Commons Attribution 4.0 International License (CC BY 4.0) http://creativecommons.org/licenses/by/4.0/deed.en_GB, which permits unrestricted use, distribution, and reproduction in any medium, provided the original author(s) and source are credited. 
élevé. L'abondance des fleurs des deux espèces était plus faible dans les parcelles ombragées et le pic de floraison était retardé ( 3 à 8 jours) par rapport aux témoins. Les changements de calendrier peuvent entraîner des décalages phénologiques et avoir un impact sur d'autres niveaux trophiques dans l'Arctique, car les fleurs et les baies qui en résultent sont des sources de nourriture importantes pour les animaux. [Traduit par la Rédaction]

Mots-clés : busserole, airelle vigne d'Ida, phénologie, changement climatique, Vaccinium vitis-idaea, Arctous alpina.

\section{Introduction}

Warming in the Arctic has been accelerating in the past 50 years at higher rates compared with lower latitude regions (ACIA 2005; IPCC 2018). Warming in the Arctic has also been shown to alter environmental conditions such as snow and precipitation (Callaghan et al. 2011; Liston and Hiemstra 2011; Cohen et al. 2012; Bintanja and Selten 2014). Changes in the physical environment have been associated with shifts in plant community phenology and increased plant cover (Arft et al. 1999; Elmendorf et al. 2012; Oberbauer et al. 2013; Bjorkman et al. 2018; Prevéy et al. 2017). Erect shrub expansion has been well documented as a consequence of warming temperatures and often results in shifts in the competitive landscape resulting in prostrate plants being out-competed (Tape et al. 2006; Myers-Smith et al. 2011; Loranty and Goetz 2012; Tape et al. 2012; Myers-Smith et al. 2015). The expansion of erect shrub cover may result in shading that adversely affects prostrate plants within the community.

Shading has been documented as one key constraint on the growth of Arctic plant species (Billings 1987). Some studies have found that shade has little effect on plant growth, especially when compared with other treatment types such as warming or nutrient additions (Graglia et al. 1997; Jonasson et al. 1999; Shaver and Jonasson 1999; Gough et al. 2002; Weijers et al. 2013). In contrast, other studies have shown that shading lowers carbon uptake (Havström et al. 1993, Michelsen et al. 1996; Dahl et al. 2017). Past studies investigating the impact of shading on Arctic plants have focused on plant growth and physiology (Michelsen et al. 1996; Illeris et al. 2004; Hansen et al. 2006; Olsrud and Michelsen 2009; Campioli et al. 2012). These alterations in carbon assimilation may influence the resource reserves available for floral density and phenology.

Despite the literature on the effects of shading on growth rates and physiology, to the best of our knowledge no studies have investigated the impacts of canopy shading on plant phenology and reproductive effort. Changes in floral density and timing have the potential to have ripple effects across trophic levels, impacting pollinators (Armbruster and Guinn 1989; Høye et al. 2013; Høye et al. 2014), as well as birds and mammals that feed on resulting berries (Cottam 1936; Kapel 1999; MacHutchon and Wellwood 2003; Ikeda et al. 2015; Thompson et al. 2016) Understanding how shading from canopy vegetation may impact flower timing and number in the understory is important to our understanding of how prostrate plants should perform in the face of climate change and erect shrub expansion (Wookey et al. 1993; Thórhallsdóttir 1998; Høye et al. 2013; Wheeler et al. 2015).

Here, we examine the effects of two levels of in situ shade manipulations in two community types that are widespread across the Arctic. Dry heath and moist acidic tundra communities were chosen due to the high density of berry producing species and variation in natural shading. We implemented both $40 \%$ and $80 \%$ reduction in ambient light, to investigate how shade impacts phenology and reproductive effort of prostrate species, Arctous alpina L. and Vaccinium vitis-idaea L. Specifically, we monitored flower number and timing, surface temperature, soil moisture, and normalized difference vegetation index (NDVI) over two years. It was expected that shading will lower surface temperature and increase soil 
moisture as a result of less solar radiation reaching both the canopy and ground. We also expected shading to decrease plant NDVI values, delay the timing of peak flowering, and reduce the number of flowers in a plot.

\section{Methods}

The study sites included a dry heath and moist acidic plant community near Toolik Lake on the North Slope of Alaska (Fig. 1, 68 $37^{\prime} \mathrm{N}, 149^{\circ} 36^{\prime} \mathrm{W}, 736 \mathrm{~m}$ above sea level). The dry heath community was dominated by V. vitis-idaea, A. alpina, Empetrum nigrum L., and lichens. The moist acidic community was dominated by Eriophorum vaginatum L., Salix pulchra Cham., Betula nana L., V. vitis-idaea, and sphagnum moss. Moist acidic plots were randomly selected to be within the inter-tussock space and established in areas with few erect shrubs to minimize natural shading from erect shrubs and E. vaginatum. Within each community type we established 18 plots consisting of 6 control (no shade), 6 low shade (40\% shade cloth), and 6 high shade (80\% shade cloth) plots. Shading levels were selected based on preliminary observations taken under various erect shrub canopies, with medium shrub leaf and stem densities measure approximately $40 \%$ incoming light reduction and the highest shading approximately $80 \%$ light reduction. Each plot was $25 \mathrm{~cm} \times 25 \mathrm{~cm}$. Shade cloth was installed at a height of $10 \mathrm{~cm}$ and was stretched and attached to a wire frame to maintain integrity with a gap above ground level to a height of approximately $3 \mathrm{~cm}$ to allow air flow and prevent surface heating (Supplementary material $1^{1}$ ). The shade cloth was a UV-resistant, neutral density woven polyethylene fabric that allows water permeation and air ventilation while reducing solar radiation (PC Pools, Libertyville, Illinois, USA). Neutral density fabric was used to reduce incoming solar radiation while not altering the spectrum of incoming light.

Plots were established in late June of 2016. Sampling was conducted during the second (2017) and third (2018) years of shade manipulation on the two focal species of the study, $V$. vitis-idaea and A. alpina. Shade cloth was installed shortly after snow-melt (early June) and removed before the first snowfall (late August) every year. During the 2017 and 2018 sampling periods each plot was monitored twice weekly for flower phenology, plot- and leaf-level normalized difference vegetation index (NDVI), surface temperature, and soil moisture content. Flower phenology was monitored visually by counting the number of flower buds, open flowers, and withered flowers at each sampling time for both focal species of the study. Fruit production was not monitored due to potential interference by the shade cloth with pollinator visitation. Plot-level NDVI values were monitored near solar noon using ambient light at a height of approximately $15 \mathrm{~cm}$ from ground surface using a single channel Unispec spectrophotometer (PP Systems, Amesbury, Massachusetts, USA). Leaf-level NDVI values were monitored using a single channel Unispec spectrophotometer with a leaf-clip attachment clipped on 5 representative leaves on different individuals from each focal species in each plot with $100 \%$ light source on. Both plot- and leaf-level NDVI were calculated using the normalized difference between near-infrared $\left(R_{774}\right)$ and red $\left(R_{656}\right)$ light wavelength reflectance $\left(\mathrm{NDVI}=\left(\mathrm{R}_{774}-\mathrm{R}_{656}\right) /\left(\mathrm{R}_{774}+\mathrm{R}_{656}\right)\right.$ ) (May et al. 2017; Jiang et al. 2019). Shade cloth was briefly removed from plots to facilitate taking both plot and species-level NDVI measurements. Surface temperature was measured at a height of approximately $30 \mathrm{~cm}$ using a Fluke $62 \mathrm{Max}^{\circledR}$ infrared thermometer (Fluke Corporation, Everett, Washington, USA) aimed at the ground surface immediately after removing shade cloth for measurements. Soil moisture content was measured at a depth of $5 \mathrm{~cm}$ in the center

${ }^{1}$ Supplementary data are available with the article at https://doi.org/10.1139/as-2020-0043. 
Fig. 1. Plot layout in dry heath and moist acidic communities (A), and location of study sites at Toolik Lake, Alaska $\left(68^{\circ} 37^{\prime} \mathrm{N}, 149^{\circ} 36^{\prime} \mathrm{W}, 736 \mathrm{~m}\right.$ above sea level (B) (created using Google Earth (Google n.d.)).

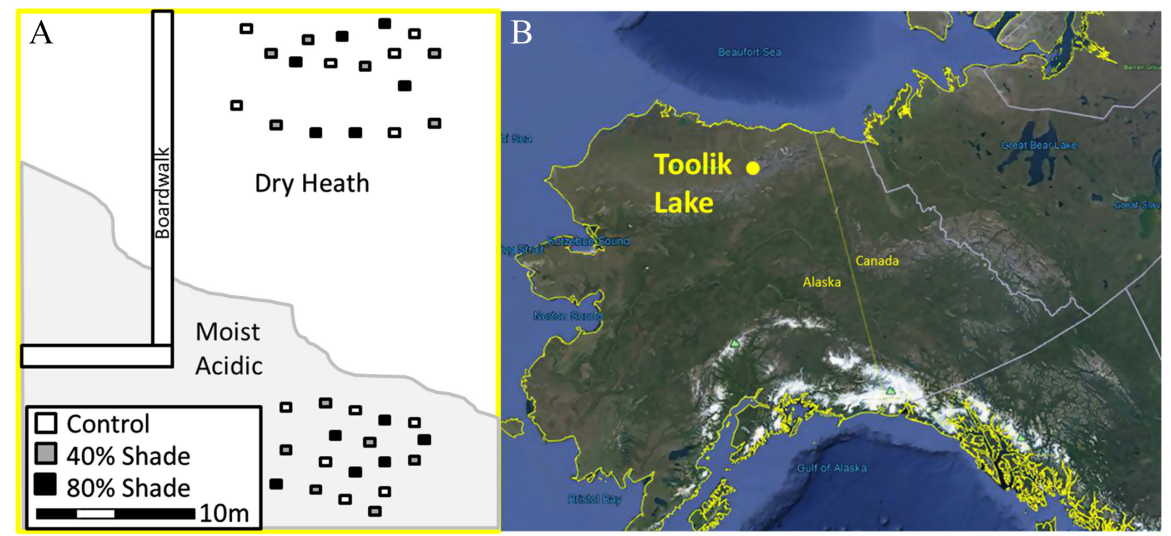

of each plot using a Decagon EC-5 soil moisture sensor (Decagon Devices, Pullman, Washington, USA).

All statistical tests were performed using the R statistical environment version 3.6.2 (R Core Team 2018). Flower phenology for each species, plot-level NDVI, and leaf-level NDVI for each species measurements were used to determine the magnitude and timing of peak value and compared using repeated measure analysis of variance (RANOVA) with Tukey's post-hoc analysis. Each variable was first tested for normality to ensure the validity of the statistical tests applied for analysis. Surface temperature and soil moisture content measurements were aggregated by treatment type and month and compared with the control treatment using a RANOVA.

\section{Results}

Shaded plots had reduced the surface temperature at both sites across almost all months of the study (Fig. 2, Supplementary material $2^{1}$ ). Surface temperature decreases were overall smaller in the moist acidic community $\left(14.4{ }^{\circ} \mathrm{C}\right.$ control to $13.7^{\circ} \mathrm{C} 40 \%$ and $\left.12.6{ }^{\circ} \mathrm{C} 80 \%\right)$ compared with the dry heath $\left(15.2^{\circ} \mathrm{C}\right.$ control to $13.9{ }^{\circ} \mathrm{C} 40 \%$ to $\left.10.9{ }^{\circ} \mathrm{C} 80 \%\right)$. In dry heath, both $80 \%$ and $40 \%$ shade levels had lower surface temperature significantly across all 3 months of the growing season, with the largest decreases in July $\left(18.2{ }^{\circ} \mathrm{C}\right.$ control to $12.9^{\circ} \mathrm{C}$ and $15.0^{\circ} \mathrm{C}$, respectively). In the moist acidic community, surface temperature decreases were the largest in July for both $80 \%$ and $40 \%$ shade levels $\left(17.9^{\circ} \mathrm{C}\right.$ control to $16.1^{\circ} \mathrm{C}$ and $16.8^{\circ} \mathrm{C}$, respectively).

Soil moisture, on average, was higher in shaded plots at both communities, with the greatest differences in July (Fig. 3, Supplementary material $2^{1}$ ). The highest shading $(80 \%)$ significantly increased soil moisture content in the dry heath across all 3 months of the growing season (June: $18.3 \%$ control to $19.9 \%$, July: $8.7 \%$ control to $14.3 \%$, August: $14.4 \%$ control to 16.3\%). Both levels of shading only increased soil moisture content in July in the moist acidic community (19.3\% control to $80 \%: 21.2 \%$ and $40 \%: 20.6 \%$ ), but not in June (33.6\% control to $80 \%: 34.4 \%$ and $40 \%: 34.2 \%$ ) or August (24.6\% control to $80 \%: 25.5 \%$ and 40\%: $25.1 \%)$.

The highest shading level (80\%) decreased both plot- and species-level NDVI values over both years compared with control plots (Fig. 4, Supplementary material $2^{1}$ ). Peak plot level NDVI in the dry heath community was lower in both study years under 
Fig. 2. Surface temperature difference between control and shade treatment plots ( $80 \%$ and $40 \%)$ by month in dry heath (A) and moist acidic (B) communities. Statistical difference denoted by ${ }^{*}$ ( $p$ value $<0.05$ ).

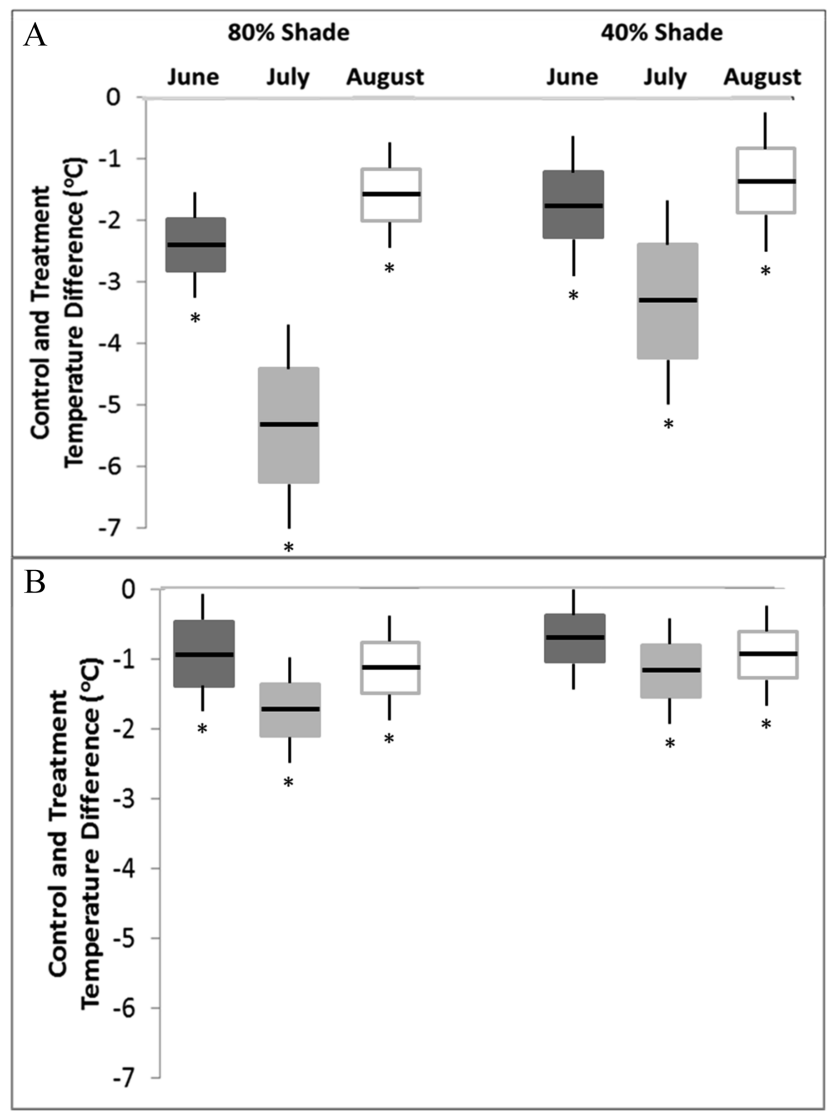

80\% (2017: $-0.043 \pm 0.025$ (SE), 2018: $-0.063 \pm 0.012$ (SE)) but not $40 \%$ shade. Vaccinium vitis-idaea and $A$. alpina in the dry heath community had no change in peak NDVI value at $40 \%$ shade but had decreased NDVI at $80 \%$ shade for both 2017 (V. vitis-idaea: $-0.051 \pm .018$ (SE), A. alpina: $-0.041 \pm 0.021$ (SE)) and 2018 (V. vitis-idaea: $-0.048 \pm 0.019$ (SE), A. alpina: $-0.066 \pm 0.017$ (SE)). Maximum NDVI values for both plot-level and $V$. vitis-idaea in the moist acidic plots decreased at the $80 \%$ shade for both $2017(-0.059 \pm 0.021$ (SE) and $-0.046 \pm 0.023$ (SE) respectively) and $2018(-0.049 \pm 0.019$ (SE) and $-0.061 \pm 0.022$ (SE)); however peak NDVI values did not change at the $40 \%$ shade level.

Both shade levels (40\% and $80 \%$ ) delayed the timing of plot- and species-specific peak NDVI values in the dry heath and moist acidic communities (Fig. 4, Supplementary material $2^{1}$ ). Dry heath peak NVDI values were delayed by $10 \pm 2.6$ (SE) days in 2017 and $11 \pm 2.7$ (SE) days in 2018 when shaded at $80 \%$, but had no change in timing at $40 \%$ shade. Vaccinium vitis-idaea peak NDVI values were delayed in the dry heath community at both shading levels for both 2017 (40\%: $+7 \pm 2.4$ (SE), 80\%: $+10 \pm 2.0$ (SE) days) and 2018 (40\%: +6 \pm 2.1 (SE), 80\%: $+9 \pm 1.7$ (SE) days). Arctous alpina peak NDVI values were delayed in the dry heath community at both shading levels for both 2017 (40\%: $+7 \pm 2.3$ (SE), 80\%: $+16 \pm 2.0$ (SE) days) and 2018 (40\%: $+7 \pm 2.1$ (SE), $80 \%:+13 \pm 1.7$ (SE) days). In the moist acidic community neither plot level nor $V$. vitis-idaea peak NDVI values were changed by $40 \%$ shade, but were significantly delayed by $80 \%$ shade in both 2017 (plot: $+8 \pm 1.9$ (SE), V. vitis-idaea: $+7 \pm 1.8$ (SE) days) 
Fig. 3. Soil moisture difference between control and shade treatment plots ( $80 \%$ and $40 \%)$ by month in dry heath (A) and moist acidic (B) communities. Statistical difference denoted by ${ }^{*}(p$ value $<0.05)$.

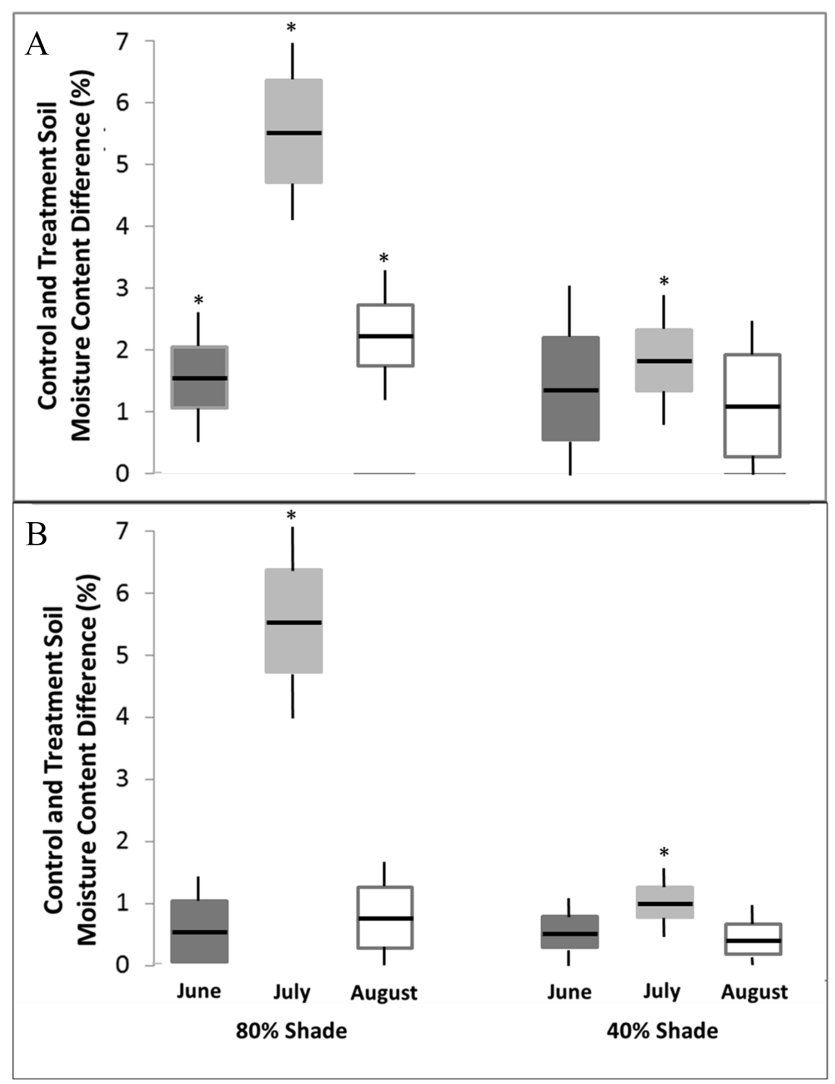

and 2018 (plot: $+9 \pm 2.0$ (SE), V. vitis-idaea: $+9 \pm 2.2$ (SE) days). Shading also impacted the end of the growing season through delayed the timing of senescence at both the dry heath and moist acidic sites (Supplementary material $3^{1}$ ).

Effects of shading varied between $V$. vitis-idaea and A. alpina; however, they generally reduced the number of flowers and delayed peak flowering (Fig. 5, Supplementary material $2^{1}$ ). Vaccinium vitis-idaea flower number in the dry heath community was unchanged by both $40 \%$ and $80 \%$ shade levels in 2017 but decreased in 2018 (40\%: $-5 \pm 1.7$ (SE) and 80\%: $-6 \pm 0.7$ (SE)). Arctous alpina flower number in the dry heath decreased at both shading levels in 2017 (40\%: $-5 \pm 1.3$ (SE) and 80\%: $-4 \pm 1.6$ (SE)) and 2018 (40\%: $-4 \pm 2.1$ (SE) and $80 \%:-7 \pm 1.4(\mathrm{SE})$ ). The frequency of $V$. vitis-idaea flowers in the moist acidic community was unchanged by both levels of shading in 2017 and 2018. The date of peak flowering was unchanged by both shade levels in 2017. In 2018 40\% shade level flowering was delayed and $80 \%$ shade delayed peak flowering for both $V$. vitis-idaea and A. alpina in 2018 $(+7 \pm 1.8$ (SE) and $+6 \pm 1.2$ (SE) days respectively). In the moist acidic community $V$. vitis-idaea was delayed in flowering at the highest shading $(80 \%)$ in $2017(+6 \pm 1.2$ (SE) days) and was delayed in both $40 \%$ and $80 \%$ shade levels in $2018(+6 \pm 2.1$ (SE) and $+8 \pm 1.9$ (SE) days respectively). 
Fig. 4. Impacts of shading on the timing and magnitude of peak normalized difference vegetation index measured at the plot-level and leaf-level on Vaccinium vitis-idaea and Arctous alpina in dry heath and moist acidic tundra communities. Values represent the means of control plots ( $2017=$ black solid circle, $2018=$ dark blue solid circle), $40 \%$ shade plots $(2017=$ grey solid circle, $2018=$ light blue solid circle), and $80 \%$ shade plots $(2017=$ black open circle, $2018=$ dark blue open circle).

Dry Heath

Moist Acidic
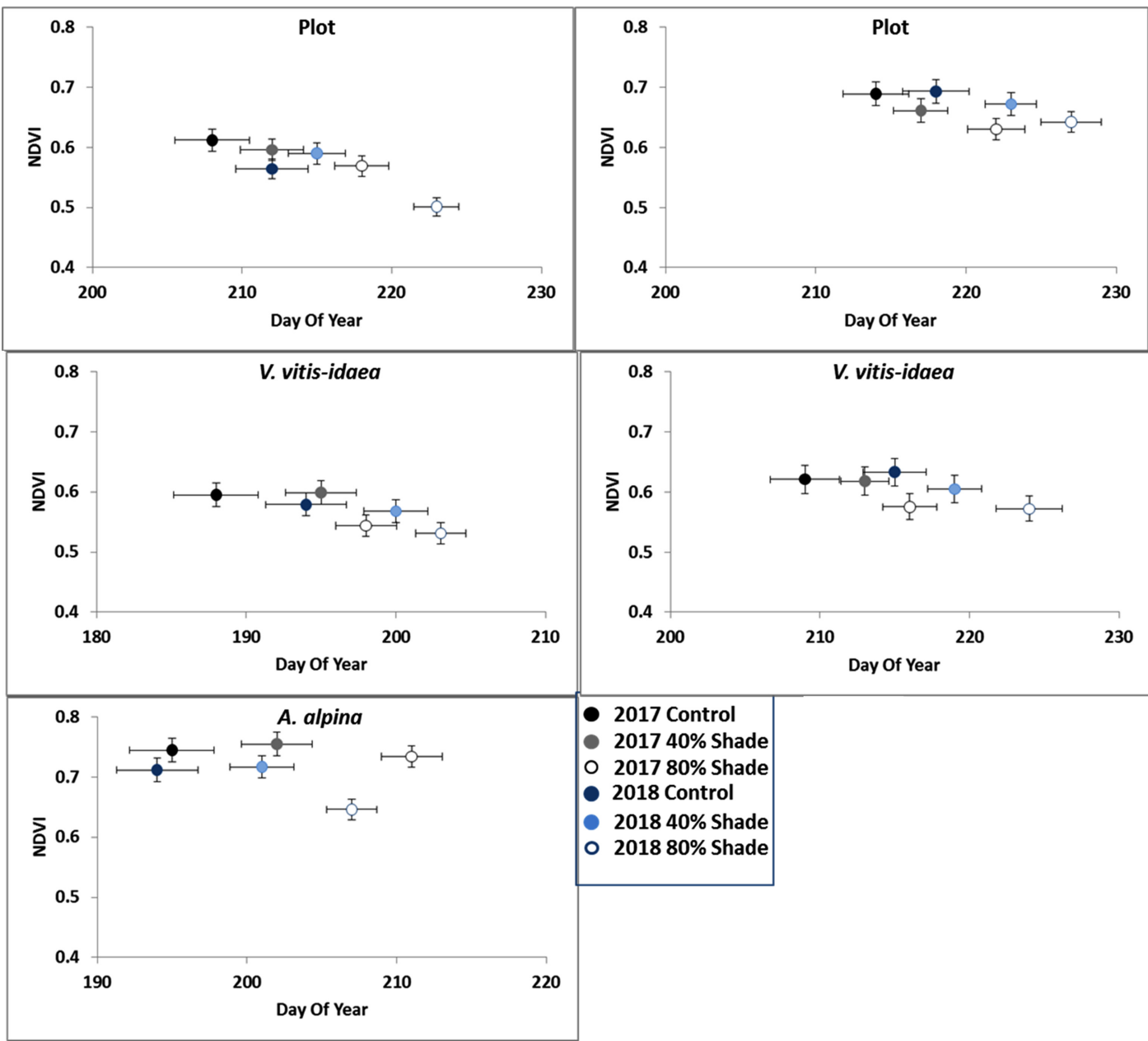

- 2017 Control

$201740 \%$ Shade

○ $201780 \%$ Shade

- 2018 Control

- $201840 \%$ Shade

○ $201880 \%$ Shade

\section{Discussion}

Only the highest levels of shading had any effect on the magnitude of peak NDVI values. The consistency of NDVI response to shading across plot-and species-level, treatment level, and year suggest that prostrate shrubs have some tolerance to moderate amounts of shading. Our study species may be adapted to open habitat, however given that $V$. vitis-idaea and A. alpina grow close to ground level it is likely that they are adapted to cope with some shading from erect shrubs. The marginal results of shading on vegetative growth and flower/fruit production has been documented in previous studies (Jonasson et al. 1999; Shaver and Jonasson 1999; Weijers et al. 2013) and is consistent with the limited impact of lower levels of shading on NDVI from this study. The response of peak NDVI value to shading was larger in the dry heath community, which may be attributed to the higher 
Fig. 5. Impacts of shading on the timing and magnitude of flowering of Vaccinium vitis-idaea and Arctous alpina in dry heath and moist acidic tundra communities. Values represent the means of control plots $(2017=$ black solid circle, 2018 = dark blue solid circle), $40 \%$ shade plots ( 2017 = grey solid circle, $2018=$ light blue solid circle), and $80 \%$ shade plots ( $2017=$ black open circle, $2018=$ dark blue open circle).

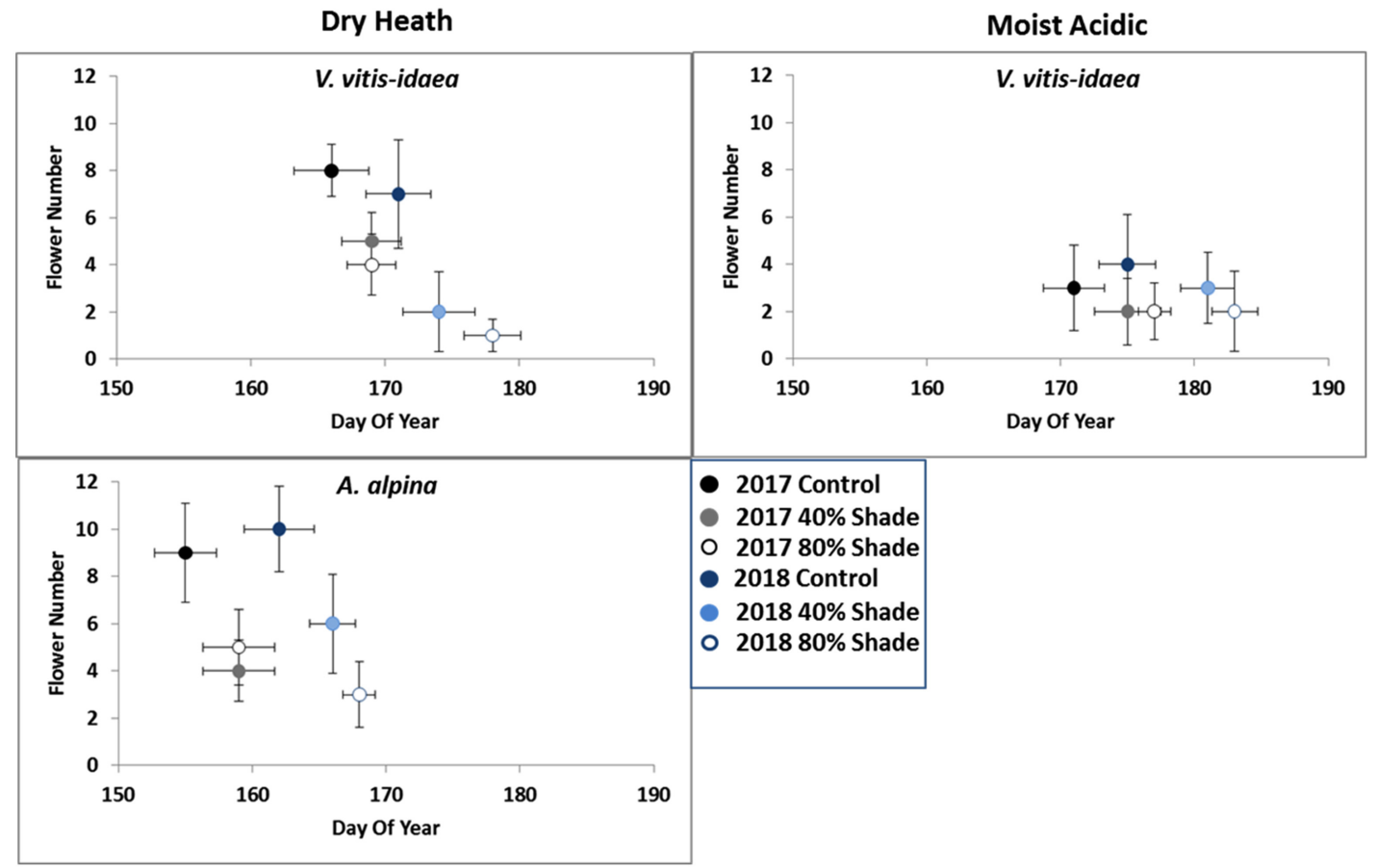

frequency of lichen ground cover and bare ground muting the reflectance differences between treatments. Shading also delayed plot-level senescence in both dry heath and moist acidic plots however the magnitude of this delay varied between sampling years (Supplementary material 2, $3^{1}$ ).

The impact of shading on the number of flowers produced varied across communities and species in our study. Arctous alpina showed the most rapid response to shading with a decrease in the number of flowers produced in both years. The reduced flowering in both study years is consistent with previous studies given that flowers are the result of initial buds that form in previous years (Remphrey et al. 1983; Remphrey and Steeves 1984; Shevtsova et al. 1995; Tolvanen 1995) and given that the first year of measurements in our study was the second year of shading. In contrast, $V$. vitis-idaea did not show a decrease in flowering until the second year of measurements (third year of shading) in the dry heath and had no change in the moist acidic community. The variation in the speed and magnitude of flowering between the two study species suggests that there is likely a difference in the time required for flowers to develop (Adams 1940; Holloway 1983; Shevtsova et al. 1995). Our results also suggest that $V$. vitis-idaea may possess an inherent tolerance to shading that allows the capacity to produce flowers to not be impacted by all but the highest shade levels. Higher shade tolerance may allow $V$. vitis-idaea to become established and be common in moist acidic communities and lower latitudes (boreal forest), in addition to the dry heath, where shading from a taller canopy is more likely. Alternatively, A. alpina is almost exclusively present in dry heath communities where neighboring plants are shorter 
and sparser making shading less likely and ultimately making shade tolerance less important.

Shading delayed the timing of flowering in both species; however, this was most evident at the highest shading levels and in the second year of treatment. Delayed flowering was likely caused by a decline in photosynthetic capacity due to shading, coupled with the lower surface temperate. Both study species show an additive effect of shading over the length of the study resulting in lower flowering frequency and delayed flowering peak after three years of shading treatment. The impacts of shading over multiple years may result in fewer flower buds being formed and, in turn, reducing the reproductive fitness of these two species. Any ability of the two focal species to adapt (e.g., lengthening branches, increased photosynthetic efficiency at lower light, etc.) to changes in their physical environments may be beneficial to their survival in the face of both climate and community structure changes (Kudo and Suzuki 2003; Kudo et al. 2010; Gehrmann et al. 2020).

Our shade manipulation was successful in altering the physical environment during the growing season throughout the duration of the experiment. Shading decreased surface temperature across all months of the growing season, with the largest decreases being in the middle of the growing seasons during the month of July. Sun angles are most direct during late June and early July, resulting in increased surface temperatures and thus increased surface warming. Prevention of solar radiation from reaching the ground surface cools the soil and lowers evaporation rates preventing the soil from drying out as quickly (Graglia et al. 1997; Aalto et al. 2013; Juszak et al. 2014). Similarly, but to a lesser extent, shading increased soil moisture level in all plots. Soil moisture was less affected by shading in the beginning of the growing season (June) and the end (August), likely a result of snowmelt during the early growing season and increased rainfall at the end contributing additional surface moisture. Moisture levels were more affected in the dry heath community compared with the moist acidic, which may be attributed to several factors. The dry heath community consists of mineral soil with little moss cover, compared with the moist acidic community that has more peat and moss cover allowing for more lateral movement of water. Additionally, the vegetation within the moist acidic community is taller, providing more natural shading on the soil and further preventing evaporation. Higher soil moisture in the moist acidic community type may have contributed to there being less difference in soil moisture content between treatments within the community.

Delays in peak flowering and decreases in number of flowers may result in declines in pollinator visitation frequency (Holloway et al. 2002; Høye et al. 2013; Gillespie et al. 2016). Delays in flowering, and the associated reduction in pollinator visitation, could lead to lower reproductive success in species that are more susceptible to shading (Kudo 1993; Høye et al. 2013). In our two study species, as well as other berry-producing species, any changes in reproductive fitness may impact upper trophic levels. Arctic flower pollen and nectar is an important food source for many invertebrates (Armbruster et al. 1989; Høye et al. 2013; Høye et al. 2014), and resulting berries can be a critical food source for many birds (Cottam 1936; Ikeda et al. 2015; Thompson et al. 2016) and mammals (Kapel 1999; MacHutchon and Wellwood 2003).

\section{Conclusion}

We show here that shading alters the environmental conditions surrounding prostrate shrubs by increasing soil moisture levels and decreasing surface temperature. Shading lowers the number of flowers produced by A. alpina and V. vitis-idaea and delays the peak flowering date. Changes in prostrate shrub flower phenology and reproductive effort may enhance the disadvantage these shrubs have with erect shrubs. This disadvantage coupled with a warming climate has the potential to further erode the competitiveness of prostrate 
shrubs and result in population declines (Wookey et al. 1993; Molau 1997; Auffret et al. 2010). Declines in these prostrate shrubs could potentially have ripple effects across trophic levels and the ecosystem.

\section{Funding statement}

This project was supported by funding from the National Science Foundation grants PLR-1504381 and PLR-1836898.

\section{Contributors' statement}

JLM, SLU, MJS, KRB, and SFO established study sites and led data collection. SFO and RDH secured funding to support this project. JLM, SLU, MJS, KRB, SFO, and RDH participated in manuscript development and provided comments.

\section{Data availability statement}

Data are available through https://doi.org/10.5061/dryad.n2z34tmzc and from the corresponding author.

\section{Acknowledgements}

The authors would like to thank Claudia Garcia the original impetus of the study and for assistance establishing the sites. Additionally, the authors would like to thank CH2MHill Polar Services for support and logistics during fieldwork, and the staff and management of the University of Alaska Institute of Arctic Biology and CH2MHL Polar Services for support at the Toolik Field Station.

\section{References}

Aalto, J., le Roux, P.C., and Luoto, M. 2013. Vegetation mediates soil temperature and moisture in arctic alpine environments. Arctic, Antarctic, Alp. Res. 45(4): 429-439. doi: 10.1657/1938-4246-45.4.429.

ACIA. 2005. Arctic Climate Impact Assessment 2004. Cambridge University Press.

Adams, J.E. 1940. A systematic study of the genus Arctostaphylos Adans. J. Elisha Mitchell Sci. Soc. 56(1): 1-62.

Armbruster, W.S., and Guinn, D.A. 1989. The solitary bee fauna (Hymenoptera: Apoidea) of interior and arctic Alaska: flower associations, habitat use, and phenology. J. Kansas Entomol. Soc. 468-483.

Arft, A.M., Walker, M.D., Gurevitch, J.E.T.A., Alatalo, J.M., Bret-Harte, M.S., Dale, M., et al. 1999. Responses of tundra plants to experimental warming: meta-analysis of the international tundra experiment. Ecol. Mono. 69(4): 491-511.

Auffret, A.G., Meineri, E., Bruun, H.H., Ejrnæs, R., and Graae, B.J. 2010. Ontogenetic niche shifts in three Vaccinium species on a sub-alpine mountain side. Plant Ecol. Divers. 3(2): 131-139. doi: 10.1080/17550874.2010.498063.

Bintanja, R., and Selten, F.M. 2014. Future increases in Arctic precipitation linked to local evaporation and sea-ice retreat. Nature, 509(7501): 479-482. doi: 10.1038/nature13259. PMID: 24805239.

Bjorkman, A.D., Myers-Smith, I.H., Elmendorf, S.C., Normand, S., Rüger, N., and Beck, P.S., et al. 2018. Plant functional trait change across a warming tundra biome. Nature, 562(7725): 57-62. doi: 10.1038/s41586-018-0563-7.

Billings, W.D. 1987. Constraints to plant growth, reproduction, and establishment in arctic environments. Arct. Alp. Res., 19(4): 357-365. doi: 10.2307/1551400.

Callaghan, T.V., Johansson, M., Brown, R.D., Groisman, P.Y., Labba, N., Radionov, V., et al. 2011. The changing face of Arctic snow cover: A synthesis of observed and projected changes. Ambio, 40(S1), 17-31. doi: 10.1007/s13280-0110212-y.

Campioli, M., Leblans, N., and Michelsen, A. 2012. Twenty-two years of warming, fertilisation and shading of subarctic heath shrubs promote secondary growth and plasticity but not primary growth. PLoS One, 7(4): e34842. doi: 10.1371/journal.pone.0034842. PMID: 22511968.

Cohen, J.L., Furtado, J.C., Barlow, M.A., Alexeev, V.A., and Cherry, J.E. 2012. Arctic warming, increasing now cover and widespread boreal winter cooling. Environ. Res. Lett. 7(1): 014007. doi: 10.1088/1748-9326/7/1/014007.

Cottam, C. 1936. Food of Arctic birds and mammals collected by the Bartlett Expeditions of 1931, 1932, and 1933. J. Wash. Acad. Sci., 26(4): 165-177.

Dahl, M.B., Priemé, A., Brejnrod, A., Brusvang, P., Lund, M., Nymand, J., et al. 2017. Warming, shading and a moth outbreak reduce tundra carbon sink strength dramatically by changing plant cover and soil microbial activity. Sci Rep, 7(1): 1-13. doi: 10.1038/s41598-017-16007-y.

Elmendorf, S.C., Henry, G.H., Hollister, R.D., Björk, R.G., Boulanger-Lapointe, N., Cooper, E.J., et al. 2012. Plot-scale evidence of tundra vegetation change and links to recent summer warming. Nat. Clim. Change, 2(6): $453-457$. doi: 10.1038/nclimate1465. 
Gehrmann, F., Lehtimäki, I.M., Hänninen, H., and Saarinen, T. 2020. Sub-Arctic alpine Vaccinium vitis-idaea exhibits resistance to strong variation in snowmelt timing and frost exposure, suggesting high resilience under climatic change. Polar Biol. 43(10): 1453-1467. doi: 10.1007/s00300-020-02721-3.

Gillespie, M.A., Baggesen, N., and Cooper, E.J. 2016. High Arctic flowering phenology and plant pollinator interactions in response to delayed snow melt and simulated warming. Environ. Res. Lett., 11(11): 115006. doi: 10.1088/1748-9326/11/11/115006.

Gough, L., Wookey, P.A., and Shaver, G.R. 2002. Dry heath arctic tundra responses to long-term nutrient and light manipulation. Arctic, Antarctic, and Alpine Research, 34(2): 211-218. doi: 10.1080/15230430.2002.12003486.

Graglia, E., Jonasson, S., Michelsen, A., and Schmidt, I.K. 1997. Effects of shading, nutrient application and warming on leaf growth and shoot densities of dwarf shrubs in two arctic-alpine plant communities. Ecoscience, 4(2): 191-198. doi: 10.1080/11956860.1997.11682395.

Hansen, A.H., Jonasson, S., Michelsen, A., and Julkunen-Tiitto, R. 2006. Long-term experimental warming, shading and nutrient addition affect the concentration of phenolic compounds in arctic-alpine deciduous and evergreen dwarf shrubs. Oecologia, 147(1): 1-11. doi: 10.1007/s00442-005-0233-y. PMID: 16180043.

Havström, M., Callaghan, T.V., and Jonasson, S. 1993. Differential growth responses of Cassiope tetragona, an arctic dwarf-shrub, to environmental perturbations among three contrasting high and subarctic sites. Oikos, 389-402. doi: $10.2307 / 3544933$.

Holloway, P.S. 1983. Studies on vegetative and reproductive growth of lingonberry, Vaccinium vitis-idaea L. University of Minnesota, $296 \mathrm{pp}$.

Holloway, P.S., Kruse, J.J., and Davis, A.N. August, 2002. Insect visitors and potential pollinators of lingonberries, Vaccinium vitis-idaea subsp. minus, in sub-arctic Alaska. In XXVI International Horticultural Congress: Berry Crop Breeding, Production and Utilization for a New Century 626. pp. 433-438.

Høye, T.T., Post, E., Schmidt, N.M., Trøjelsgaard, K., and Forchhammer, M.C. 2013. Shorter flowering seasons and declining abundance of flower visitors in a warmer Arctic. Nat. Clim. Change, 3(8): 759-763. doi: 10.1038/ nclimate1909.

Høye, T.T., Eskildsen, A., Hansen, R.R., Bowden, J.J., Schmidt, N.M., and Kissling, W.D. 2014. Phenology of high-arctic butterflies and their floral resources: species-specific responses to climate change. Curr Zool 60(2): 243-251. doi: 10.1093/czoolo/60.2.243.

Illeris, L., König, S.M., Grogan, P., Jonasson, S., Michelsen, A., and Ro-Poulsen, H 2004. Growing-season carbon dioxide flux in a dry subarctic heath: responses to long-term manipulations. Arct. Antarct. Alp. Res. 36(4): 456-463. doi: 10.1657/1523-0430(2004)036[0456:GCDFIA]2.0.CO;2.

I.P.C.C. 2018. Special Report on the impacts of global warming of $1.5 \mathrm{C}$ above pre-industrial levels and related global greenhouse gas emission pathways, in the context of strengthening the global response to the threat of climate change, sustainable development, and efforts to eradicate poverty. Intergovern. Panel Clim. Change.

Ikeda, H., Yoneta, Y., Higashi, H., Eidesen, P.B., Barkalov, V., Yakubov, V., et al. 2015. Persistent history of the birddispersed arctic-alpine plant Vaccinium vitis-idaea L.(Ericaceae) in Japan. J. Plant Res. 128(3): 437-444. doi: 10.1007| s10265-015-0709-8. PMID: 25773306.

Jiang, R., Wang, P., Xu, Y., Zhou, Z., Luo, X., and Lan, Y. 2019. A Novel Illumination Compensation Technique for Multi-Spectral Imaging in NDVI Detection. Sensors, 19(8): 1859. doi: 10.3390/s19081859.

Jonasson, S., Michelsen, A., Schmidt, I.K., and Nielsen, E.V. 1999. Responses in microbes and plants to changed temperature, nutrient, and light regimes in the arctic. Ecology, 80(6): 1828-1843. doi: 10.1890/0012-9658(1999) 080[1828:RIMAPT]2.0.CO;2.

Juszak, I., Erb, A.M., Maximov, T.C., and Schaepman-Strub, G. 2014. Arctic shrub effects on NDVI, summer albedo and soil shading. Remote Sens. Environ. 153: 79-89. doi: 10.1016/j.rse.2014.07.021.

Kapel, C.M. 1999. Diet of arctic foxes (Alopex lagopus) in Greenland. Arctic, 289-293.

Kudo, G. 1993. Relationship between flowering time and fruit set of the entomophilous alpine shrub, Rhododendron aureum (Ericaceae), inhabiting snow patches. Am. J. Bot. 80(11): 1300-1304. doi: 10.1002/j.1537-2197.1993.tb15368.x.

Kudo, G., and Suzuki, S. 2003. Warming effects on growth, production, and vegetation structure of alpine shrubs: a five-year experiment in northern Japan. Oecologia, 135(2): 280-287. doi: 10.1007/s00442-003-1179-6. PMID:12698350.

Kudo, G., Kimura, M., Kasagi, T., Kawai, Y., and Hirao, A.S. 2010. Habitat-specific responses of alpine plants to climatic amelioration: comparison of fellfield to snowbed communities. Arct. Antarct. Alp. Res. 42(4): $438-448$. doi: 10.1657/1938-4246-42.4.438.

Liston, G.E., and Hiemstra, C.A. 2011. The changing cryosphere: Pan-Arctic snow trends (1979 2009). J. Clim. 24(21): 5691-5712. doi: 10.1175/JCLI-D-11-00081.1.

Loranty, M.M., and Goetz, S.J. 2012. Shrub expansion and climate feedbacks in Arctic tundra. Environ. Res. Lett. 7(1): 011005. doi: 10.1088/1748-9326/7/1/011005.

MacHutchon, A.G., and Wellwood, D.W. 2003. Grizzly bear food habits in the northern Yukon, Canada. Ursus, 225-235.

May, J.L., Healey, N.C., Ahrends, H.E., Hollister, R.D., Tweedie, C.E., Welker, J.M., et al. 2017. Short-term impacts of the air temperature on greening and senescence in Alaskan arctic plant tundra habitats. Rem. Sens. 9(12): 1338. doi: $10.3390 /$ rs 9121338 .

Michelsen, A., Jonasson, S., Sleep, D., Havström, M., and Callaghan, T.V. 1996. Shoot biomass, $\delta^{13}$ C, nitrogen and chlorophyll responses of two arctic dwarf shrubs to in situ shading, nutrient application and warming simulating climatic change. Oecologia, 105(1): 1-12. doi: 10.1007/BF00328785. PMID: 28307116. 
Molau, U. 1997. Phenology and reproductive success in arctic plants: susceptibility to climate change. In Global change and Arctic terrestrial ecosystems. Springer, New York, NY. pp. 153-170.

Myers-Smith, I.H., Forbes, B.C., Wilmking, M., Hallinger, M., Lantz, T., et al. 2011. Shrub expansion in tundra ecosystems: dynamics, impacts and research priorities. Environ. Res. Lett. 6(4): 045509. doi: 10.1088/1748-9326/6/4/ 045509.

Myers-Smith, I.H., Elmendorf, S.C., Beck, P.S., Wilmking, M., Hallinger, M., Blok, D., et al. 2015. Climate sensitivity of shrub growth across the tundra biome. Nat. Clim. Change, 5(9): 887-891. doi: 10.1038/nclimate2697.

Oberbauer, S.F., Elmendorf, S.C., Troxler, T.G., Hollister, R.D., Rocha, A.V., Bret-Harte, M.S., et al. 2013. Phenological response of tundra plants to background climate variation tested using the International Tundra Experiment. Philos. Trans. R Soc. Lond. B. Biol. Sci. 368(1624): 20120481. doi: 10.1098/rstb.2012.0481.

Olsrud, M., and Michelsen, A. 2009. Effects of shading on photosynthesis, plant organic nitrogen uptake, and root fungal colonization in a subarctic mire ecosystem. Botany, 87(5): 463-474. doi: 10.1139/B09-021.

Prevéy, J., Vellend, M., Rüger, N., Hollister, R.D., Bjorkman, A.D., Myers-Smith, I.H., et al. 2017. Greater temperature sensitivity of plant phenology at colder sites: implications for convergence across northern latitudes. Global Change Biol. 23(7): 2660-2671. doi: 10.1111/gcb.13619. PMID:28079308.

R Core Team. 2018. R: A language and environment for statistical computing. R Foundation for Statistical Computing, Vienna, Austria. Available from https://www.R-project.org/.

Remphrey, W.R., Steeves, T.A., and Neal, B.R. 1983. The morphology and growth of Arctostaphylos uva-ursi (bearberry): an architectural analysis. Can. J. Bot. 61(9): 2430-2450. doi: 10.1139/b83-267.

Remphrey, W.R., and Steeves, T.A. 1984. Shoot ontogeny in Arctostaphylos uva-ursi (bearberry): origin and early development of lateral vegetative and floral buds. Can. J. Bot. 62(9): 1933-1939. doi: 10.1139/b84-264.

Shaver, G.R., and Jonasson, S. 1999. Response of Arctic ecosystems to climate change: results of long term field experiments in Sweden and Alaska. Polar Res. 18(2): 245-252. doi: 10.1111/j.1751-8369.1999.tb00300.x.

Shevtsova, A., Ojala, A., Neuvonen, S., Vieno, M., and Haukioja, E. 1995. Growth and reproduction of dwarf shrubs in a subarctic plant community: annual variation and above-ground interactions with neighbours. J. Ecol., 263-275. doi: $10.2307 / 2261565$.

Tape, K.E.N., Sturm, M., and Racine, C. 2006. The evidence for shrub expansion in Northern Alaska and the Pan-Arctic. Global Change Biol. 12(4): 686-702. doi: 10.1111/j.1365-2486.2006.01128.x.

Tape, K.D., Hallinger, M., Welker, J.M., and Ruess, R.W. 2012. Landscape heterogeneity of shrub expansion in Arctic Alaska. Ecosystems, 15(5): 711-724. doi: 10.1007/s10021-012-9540-4.

Thórhallsdóttir, T.E. 1998. Flowering phenology in the central highland of Iceland and implications for climatic warming in the Arctic. Oecologia, 114(1): 43-49. doi: 10.1007/s004420050418. PMID: 28307556.

Thompson, S.J., Handel, C.M., Richardson, R.M., and McNew, L.B. 2016. When winners become losers: predicted nonlinear responses of arctic birds to increasing woody vegetation. PLoS ONE 11(11): e0164755. doi: 10.1371/ journal.pone.0164755. PMID: 27851768.

Tolvanen, A. 1995. Aboveground growth habits of two Vaccinium species in relation to habitat. Can. J. Bot., 73(3): 465-473. doi: 10.1139/b95-047.

Weijers, S., Auliaherliaty, L., van Logtestijn, R., and Rozema, J. 2013. Effects of manipulated precipitation and shading on Cassiope tetragona growth and carbon isotope discrimination: a high Arctic field study. Arctic, antarctic, and alpine research, 45(1): 132-142. doi: 10.1657/1938-4246-45.1.132.

Wheeler, H.C., Høye, T.T., Schmidt, N.M., Svenning, J.C., and Forchhammer, M.C. 2015. Phenological mismatch with abiotic conditions_implications for flowering in Arctic plants. Ecology, 96(3): 775-787. doi: 10.1890/14-0338.1. PMID: 26236873.

Wookey, P.A., Parsons, A.N., Welker, J.M., Potter, J.A., Callaghan, T.V., Lee, J.A., and Press, M.C. 1993. Comparative responses of phenology and reproductive development to simulated environmental change in sub-arctic and high arctic plants. Oikos: 490-502. doi: 10.2307/3545361. 